\title{
CONF-981011-
}

\section{ACCIDENT SEQUENCES SIMULATED AT THE JURAGUA NUCLEAR POWER PLANT}

\author{
Juan J. Carbajo \\ Oak Ridge National Laboratory \\ Oak Ridge, Tennessee 37831-8057
}

PECEIVED

JUL 291998

\begin{abstract}
Different hypothetical accident sequences have been simulated at Unit 1 of the Juragua nuclear power plant in Cuba, a plant with two VVER-440 V213 units under construction. The computer code MELCOR was employed for these simulations. The sequences simulated are: (1) a design-basis accident (DBA) large loss of coolant accident (LOCA) with the emergency core coolant system (ECCS) on, (2) a station blackout (SBO), (3) a small LOCA (SLOCA) concurrent with SBO, (4) a large LOCA (LLOCA) concurrent with SBO, and (5) a LLOCA concurrent with SBO and with the containment breached at time zero. Timings of important events and source term releases have been calculated for the different sequences analyzed. Under certain weather conditions, the fission products released from the severe accident sequences may travel to southern Florida.
\end{abstract}

\footnotetext{
* Work sponsored by the Defense Special Weapons Agency, U.S. Department of Defense. ** Managed by Lockheed Martin Energy Research Corp. for the U.S. Department of Energy, under contract No. DE-AC05-960R22464
}

The submitted manuscript has been authored by a contractor of the U.S. Government under contract No. DE-ACOS-96OR22464. Accordingly, the U.S Government retains a non-exclusive, royalty free license to publish or reproduce the published form of this contribution, or allow others to do so, for U.S. Government purposes.

DISTRIBUTION OF THS DOCUMENT IS UMLIMITED
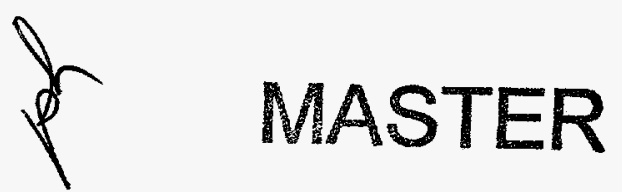


\section{DISCLAIMER}

This report was prepared as an account of work sponsored by an agency of the United States Government. Neither the United States Government nor any agency thereof, nor any of their employees, makes any warranty, express or implied, or assumes any legal liability or responsibility for the accuracy, completeness, or usefulness of any information, apparatus, product, or process disclosed, or represents that its use would not infringe privately owned rights. Reference herein to any specific commercial product, process, or service by trade name, trademark, manufacturer, or otherwise does not necessarily constitute or imply its endorsement, recommendation, or favoring by the United States Government or any agency thereof. The views and opinions of authors expressed herein do not necessarily state or reflect those of the United States Government or any agency thereof. 


\section{DISCLAIMER}

Portions of this document may be illegible in electronic image products. Images are produced from the best available original document. 


\section{INTRODUCTION}

Different accident sequences have been simulated at Unit 1 of the Juragua nuclear power plant in Cuba, a plant with two VVER-440 V213 reactors. This study has calculated the timings of important events and source terms released to the containment and to the environment for five different hypothetical accident sequences.

The severe accident code MELCOR, ${ }^{1}$ Version 1.8.4 QK, was employed in these calculations. The MELCOR code, developed under U.S. Nuclear Regulatory Commission (NRC) sponsorship, is the state of the art severe accident analysis code. MELCOR is a fully integrated code capable of simulating a complete severe accident sequence in a light water reactor (LWR). The code can calculate timing of events and source term releases into the containment and into the environment.

The Juragua plant, located near Cienfuegos in Cuba, is under construction (only $75 \%$ completed) with no completion date scheduled. Therefore, the hypothetical accidents considered in this study cannot take place until the plant is completed and in operation. However, studying the possible consequences of different hypothetical accidents at this plant is important because under certain weather conditions potential radioactive releases may reach parts of southern Florida.

\section{THE VVER REACTORS}

The information in this Section was compiled from References 2, 3 and 4.

The Soviet-made VVERs or WWERs are pressurized water reactors (PWR) similar to the United States- (U.S.) made PWRs. There are two types of VVER reactors: 440s and 1000s. The VVER-440 reactors have six loops, six primary coolant pumps, isolation valves on each loop, six horizontal steam generators, one pressurizer, rack and pinion control rod drives, and hexagonal fuel assemblies. The number 440 is the electric power in MWe that can produce the reactor, which employs two turbines of $220 \mathrm{MWe}$ each. The thermal power of the reactor is 1,375 MWth. 
There are also two subtypes of VVER-440 reactors: the older V230, with 11 units in operation (one in Armenia, four in Bulgaria, four in Russia, and two in Slovakia) and the newer V213, with 16 units in operation and 6 more units under construction. The V213 units in operation are in the Czech Republic (4 units at Dukovany), in Finland ( 2 units at Loviisa), Hungary ( 4 units at Paks), Russia ( 2 units at Kola), Slovakia ( 2 units at Bohunice), and Ukraine ( 2 units at Rovno). The 6 units under construction are in Cuba ( 2 units at Juragua) and in Slovakia ( 4 units at Mochovce).

Finally, the VVER-1000 reactors are larger reactors rated at 1,000 MWe, and 3,000 MWth. There is a total of 20 VVER-1000 reactors in operation in the following countries: Bulgaria (2 units at Kozloduy), Russia ( 7 units in total, 4 units at Balakovo, 2 units at Kalinin, and 1 unit at Novovoronezh), and Ukraine (11 units in total, 6 units at Zaporozhye, 3 units at Nikolaev, South Ukraine, 1 unit at Rovno, and 1 unit at Khmelnytskyy). There are 11 VVER-1000 units either under construction or planned.

The plants with VVER-440 reactors in general do not have a strong containment building, which is standard in the U.S.-built reactors. There are, however, two exceptions: the Loviisa plant in Finland ( 2 units in operation) that has full containment with ice beds, similar to the ice-condenser containment concept in the U.S., and the Juragua plant in Cuba ( 2 units under construction) that, when completed, will have full containment with pressure suppression pools. All the plants with VVER-1000 reactors have full-containment buildings.

The VVER-440 plants rely on the "accident localization system" (ALS) to prevent the release of fission products to the environment in the case of an accident. The model V230 has an ALS free volume of $10,000 \mathrm{~m}^{3}\left(350,000 \mathrm{ft}^{3}\right)$, which can accommodate a design basis accident (DBA) of a 10-cm (3.9-in.) diameter pipe rupture, carrying undirectional flow. Accidents with larger pipe ruptures will result in leakage to the environment as the ALS will not be able to accommodate the resulting pressure. The V230 reactors do not have Emergency Cooling Systems (ECCS); they only have makeup coolant pumps with limited injection capabilities into the reactor vessel.

The model V213 has an improved ALS with a larger free volume $\left(50,000 \mathrm{~m}^{3}\right.$ or $\left.1,750,000 \mathrm{ft}^{3}\right)$, and a "bubbler/condenser tower" that can condense steam. The DBA for this reactor model is a double-ended, guillotine break of a $50-\mathrm{cm}(20$-in.) diameter primary system pipe. 
The VVER-440 V213 plants also have ECCS with high-pressure and low-pressure injection pumps into the vessel, four accumulators, and three independent spray systems in the containment.

All 16 VVER-440 V213 units in operation are similar with the exception of the two units at Loviisa in Finland. The Loviisa plant, although classified as a VVER-440 model V213, is actually an improved version of the VVER-440 model V230, and as such, it could be included into the model V230 plants.

\section{THE JURAGUA PLANT}

The two units of the Juragua plant in Cuba are VVER-440s model V213, and when completed, they will have full-containment buildings. The Juragua containment is a steel-lined, cylindrical reinforced concrete structure, $48 \mathrm{~m}$ in diameter, with a hemispherical dome on the top (Figure 1). The total height of the containment is $69.7 \mathrm{~m}$, and its total internal free volume is $62,420 \mathrm{~m}^{3}$. Internal suppression pools, also called "bubbler/condensers," containing $780 \mathrm{~m}^{3}$ of borated water are designed to condense steam in the containment and limit pressure increases after a loss of coolant accident (LOCA). The suppression pools separate the top big volume or operating floor

of the containment from the bottom portion where the reactor and the primary system are located. Passive and active sprays are also employed to control the pressure inside the containment.

Figure 1 shows the sprays located in the steam generator room, the spray pump (No. 4), the water storage tank (No. 5), the heat exchanger for the sprays (No. 6), and spray valves (No. 7).

A detailed MELCOR model of Unit 1 of the Juragua plant was prepared modifying a deck of the Paks plant in Hungary (also a VVER 440 V213) prepared by Gyorgy Gyenes, Atomic Energy Research Institute, Budapest, Hungary. The Juragua model consists of 27 control volumes (20 control volumes model the primary system; 6 control volumes model the containment; and 1 control volume models the environment), 41 flowpaths, 112 heat structures, and 302 control functions. The core is modeled with 4 radial rings and 19 axial levels. Ring 3 includes the control rods. The core plate is at axial Level 11 . The containment is modeled by 6 control volumes, one for the top volume, one for the cavity, one for the steam-generator room, one for 
the pump room, and two volumes for the bubbler/condensers (Figure 1). The MELCOR model includes the four accumulators, the low-pressure injection system into the core, the containment spray system, and the containment bubbler/condensers. The model assumes that the containment will fail at a pressure of $0.25 \mathrm{MPa}(36.5 \mathrm{psia})$ at the dome. After containment failure by overpressure, an opening of $0.1 \mathrm{~m}^{2}$ connects the containment dome volume with the environment.

\section{MELCOR RESULTS}

Five different accidents were simulated: (1) a design-basis accident (DBA) large loss of coolant accident (LLOCA) with the emergency core coolant system (ECCS) on, (2) a station blackout (SBO), (3) a small LOCA (SLOCA) concurrent with SBO, (4) a LLOCA concurrent with SBO, and, finally, (5) a LLOCA concurrent with SBO and with the containment breached at time zero.

MELCOR-calculated timings of events for these accidents are presented in Table 1. The first accident studied, the DBA LLOCA, did not result in core damage or radioactive releases to the containment or environment. The other four accidents are severe accidents, and as such, resulted in core damage and radioactive releases to the environment. The accidents are ordered by severity (Accident 1 is not severe, the most severe is Accident 5).

The DBA LLOCA is initiated at time zero with the reactor operating at full power (1,375 MWth) by the rupture of one of the cold legs of the primary system $(50 \mathrm{~mm}$ in diameter) and the subsequent blowdown and depressurization of the system. The reactor is shut down automatically. Figure 2 shows the MELCOR-calculated pressure inside the vessel during the first $160 \mathrm{~s}$ of the transient. The vessel pressure equalizes with the containment pressure at about $150 \mathrm{~s}$.

Figure 3 shows the mass flow rates of coolant leaving both sides of the break. The mass flow rate peaks at the beginning of the transient with a value of $11,000 \mathrm{~kg} / \mathrm{s}$, decreasing to near zero at about $100 \mathrm{~s}$. The four accumulators start discharging water at $8.7 \mathrm{~s}$, ending at about $20 \mathrm{~s}$. The low pressure injection system of the ECCS starts injecting water into the vessel at $17 \mathrm{~s}$, and the containment sprays are initiated at $60 \mathrm{~s}$. The accident is recovered without core damage. No fission products are released into the containment nor into the environment. 
Figures 4 and 5 show pressures calculated inside different control volumes of the containment. The effect of the sprays can be observed after $60 \mathrm{~s}$. A peak pressure of $193 \mathrm{kPa}$ is calculated at about $4 \mathrm{~s}$ into the transient in the pump room, where the LLOCA took place. The steamgenerator room reaches a peak pressure of $185 \mathrm{kPa}$ at the same time. The top containment volume reaches a peak pressure of $153 \mathrm{kPa}$ at about $100 \mathrm{~s}$ into the transient, decreasing to $113 \mathrm{kPa}$ at the end of the calculation $(50,000 \mathrm{~s})$ as shown in Figure 5. Figure 4 also shows the pressures reported in Reference 2 for the same transient at this plant. The peak pressures calculated in Reference 2 during the first seconds of the transient are comparable to the values calculated by MELCOR. However, after $10 \mathrm{~s}$, the values calculated in Reference 2 are lower than the MELCOR-calculated values. The pressure calculated in Reference 2 for the top containment volume is always below $133 \mathrm{kPa}$, about $20 \mathrm{kPa}$ lower than the value calculated by MELCOR. The differences are due to the different computer codes and models employed and to different assumptions used by each calculation. 
Table 1. MELCOR-calculated timing of events in seconds for different accident sequences at the Juragua plant

\begin{tabular}{|c|c|c|c|c|c|}
\hline \multirow[b]{3}{*}{ Event } & \multicolumn{5}{|c|}{ Accident Sequence } \\
\hline & 1 & 2 & 3 & 4 & 5 \\
\hline & DBA LLOCA & SBO & SLOCA + SBO & LLOCA + SBO & $\begin{array}{c}\text { LLOCA + SBO + } \\
\text { containment breached }\end{array}$ \\
\hline Accident initiation & 0 & 0 & 0 & 0 & 0 \\
\hline Accumulators on & 8.7 & 36,225 & - & 8.7 & - \\
\hline Accumulators off & 20. & 36,300 & 一 & 20. & - \\
\hline ECCS on & 17. & 一 & - & - & - \\
\hline Sprays on & 60. & 一 & - & - & - \\
\hline Cladding failure & - & 13,592 & 1,954 & 721 & 380 \\
\hline Core plate failure & - & 27,100 & 7,700 & 6,500 & 5,000 \\
\hline Vessel failure & - & 36,220 & 14,815 & 12,800 & 12,700 \\
\hline Containment failure & - & 34,400 & 16,200 & 13,426 & 0 \\
\hline Releases to Environment & - & 34,400 & 16,200 & 13,420 & 500 \\
\hline Calculation ended & 5,000 & 60,000 & 20,000 & 40,000 & 24,600 \\
\hline
\end{tabular}

Note: Accident sequences 3 and 5 have the accumulators deactivated. 
The DBA LLOCA does not result in core damage because the ECCS (low-pressure injection) is available and actuated, and it does not result in containment failure because the sprays are activated. If the ECCS is not available, core damage and vessel failure will result. However, if the containment sprays are operational, containment failure will not occur, despite the occurrence of vessel failure. These conclusions were corroborated by the results of an additional MELCOR calculation simulating the DBA LLOCA without the ECCS but with the sprays operational.

The second accident analyzed is the SBO. This sequence starts at time zero with the reactor at full power followed by scram when the electric power is lost. The water inventories in the steam generators and in the vessel are slowly boiled off by the core decay heat. No water is injected into the vessel or steam generators. The vessel is maintained at high pressure $(\sim 13 \mathrm{MPa})$, with steam vented through the steam relief valves. The cladding starts failing at 13,592 $\mathrm{s}(3.8 \mathrm{~h})$ into the transient, the core plate fails at $27,100 \mathrm{~s}(7.5 \mathrm{~h})$, and the vessel fails at $36,220 \mathrm{~s}(10.1 \mathrm{~h})$. The vessel pressure decreases rapidly after vessel failure, and the accumulators start injecting water into the vessel. The containment fails at $34,400 \mathrm{~s}(9.6 \mathrm{~h})$, about $1 / 2 \mathrm{~h}$ before vessel failure. Figure 6 shows the calculated pressures inside the containment. A big pressure spike is calculated at $10.1 \mathrm{~h}$ when the vessel fails.

Source term releases into the environment are shown in Figure 7. Releases start after containment failure. The releases are shown by fractions of the total core inventory for each MELCOR fission product class. About $92 \%$ of the initial core inventory of MELCOR Class 1 (noble gases) is calculated to be released at the end of the calculation (17 h). For MELCOR Classes $2(\mathrm{Cs}), 5(\mathrm{Te})$, and $16(\mathrm{CsI})$, the releases at the end of calculation are about $4 \%$ of the initial core inventory for these classes. Releases from the remaining classes are less than $1 \%$ of the initial inventories.

The third accident studied is the SLOCA with a break size of $0.21 \mathrm{~m}^{2}$, corresponding to the rupture of a pipe $0.073 \mathrm{~m}$ in diameter. In this accident, loss of all power and loss of the accumulators are also assumed. Neither the ECCS nor the containment sprays are operational for this sequence. Cladding failure is calculated to occur at 1,954 s, core plate failure at 7,700 s, vessel failure at $14,815 \mathrm{~s}(4.1 \mathrm{~h})$, and containment failure at $16,200 \mathrm{~s}(4.5 \mathrm{~h})$. 
The fourth accident studied is the LLOCA concurrent with SBO (neither ECCS nor containment sprays are available). The accumulators start injecting water at $8.7 \mathrm{~s}$, the same time as the DBA LLOCA of Table 1. Since the ECCS are not available, the core degrades and cladding failure occurs at $721 \mathrm{~s}$, core plate failure at $6,500 \mathrm{~s}$, vessel failure at $12,800 \mathrm{~s}(3.6 \mathrm{~h})$, and containment failure at $13,426 \mathrm{~s}(3.73 \mathrm{~h})$. The timings of events occur earlier in the LLOCA than in the SLOCA, because in the LLOCA the coolant is lost faster, resulting in earlier core uncovery and heatup.

Figure 8 shows calculated pressures in different control volumes of the containment (cavity, steam-generators room, and top containment) for this sequence. The containment fails shortly after the vessel when core debris ejected from the vessel boils the water in the cavity. This cavity water was spilled from the primary system and from the accumulators during the initial phases of the LOCA.

MELCOR-calculated releases into the environment for the LOCA sequence are shown in Figure 9. The releases start after containment failure at $3.7 \mathrm{~h}$. Almost all the noble gases (Class 1 of MELCOR) are released in a few hours. For the remaining fission products, $4.4 \%$ of the total core inventory of CsI (Class 16) is released, followed by $4.1 \%$ of Class 2 (Cs), and $3.9 \%$ of Class $5(\mathrm{Te})$. The releases for the remaining classes are less than $1 \%$ of the total inventory of each class.

Finally, the fifth and last accident simulated is a LLOCA without ECCS, sprays, or accumulators, and with the containment breached at time zero. There is also an opening on top of the reactor room (Figure 1) connecting the lower and the upper parts of containment and, therefore, bypassing the bubbler/condenser. The timings of events in the vessel for this accident are similar to the previous LLOCA (Accident 4), although they occur a little sooner because of the lack of the accumulators. Vessel failure occurs at $12,700 \mathrm{~s}(3.53 \mathrm{~h})$, about the same time as the previous LLOCA (Accident 4).

Since the containment is breached at time zero, fission product releases start shortly after cladding failure (that occurred at $380 \mathrm{~s}$ ). The fission products reach the top volume of the containment (bypassing the bubbler/condensers), and they are released into the environment. 
Environmental releases by class are shown in Figure 10. There is a sharp increase in releases after $3.53 \mathrm{~h}$, the time of vessel failure. Almost all the noble gases (Class 1 ) are released at the end of the calculation $(-7 \mathrm{~h})$, followed by $65 \%$ of Classes $2(\mathrm{Cs})$ and $16(\mathrm{CsI}), 61 \%$ of Class 5 (Te), $19.4 \%$ of Class $12(\mathrm{Sn})$, and $17.4 \%$ of Class $3(\mathrm{Ba}, \mathrm{Sr})$. The releases for this sequence are significantly larger and occur sooner than releases calculated for any of the previous sequences. This sequence 5 is the most severe accident sequence considered in this study.

Table 2 presents the environmental releases of fission products calculated by MELCOR at the end of the calculation for three of the five sequences analyzed. The releases as a function of time were shown in Figure 7 for the SBO (Sequence 2), Figure 9 for Sequence 4, and in Figure 10 for Sequence 5 . Sequence 5 resulted in the largest releases, which start very soon after the accident is initiated. Sequences 2 and 4 have similar total releases into the environment, but they start at different times. In sequence 2 , (the SBO), the releases start much later (at $9.56 \mathrm{~h}$, Table 1) than in Sequence 4 (LLOCA+SBO), for which the releases start at $3.73 \mathrm{~h}$ (Table 1). 
Table 2. Releases into the environment as fractions of the initial inventory for three different accident sequences at the end of the calculation

\begin{tabular}{|c|c|c|c|c|}
\hline & & \multicolumn{3}{|c|}{ Accident Sequence } \\
\hline & & 2 & 4 & 5 \\
\hline MELCOR class & Element & Station Blackout & $\mathrm{LLOCA}+\mathrm{SBO}$ & $\begin{array}{l}\text { LLOCA + SBO + } \\
\text { containment breached }\end{array}$ \\
\hline 1 & Noble gases & 0.919 & 0.993 & 0.996 \\
\hline 2 & Cs & 0.043 & 0.041 & 0.647 \\
\hline 3 & $\mathrm{Ba}, \mathrm{Sr}$ & 0.006 & 0.014 & 0.174 \\
\hline 4 & $\mathrm{I}$ & - & - & - \\
\hline 5 & $\mathrm{Te}$ & 0.035 & 0.039 & 0.608 \\
\hline 6 & $\mathrm{Ru}$ & 二 & - & - \\
\hline 7 & Mo & - & - & - \\
\hline 8 & $\mathrm{Ce}$ & 0.001 & 0.003 & 0.078 \\
\hline 9 & $\mathrm{La}$ & - & - & 0.051 \\
\hline 10 & $\mathrm{U}$ & - & - & 0.002 \\
\hline 11 & $\mathrm{Cd}$ & - & 0.004 & 0.052 \\
\hline 12 & Sn & 0.003 & 0.010 & 0.194 \\
\hline 16 & CsI & 0.043 & 0.044 & 0.648 \\
\hline \multirow[t]{2}{*}{ End of calculation } & (s) & 60,000 & 40,000 & 24,655 \\
\hline & (h) & 16.7 & 11.1 & 6.85 \\
\hline
\end{tabular}




\section{CONCLUSIONS}

The severe accident code MELCOR, Version 1.8.4 QK, has been employed to calculate timing of events and source term releases for five different hypothetical accidents taking place at Unit 1 of the Juragua nuclear power plant in Cuba. The Juragua nuclear power plant in Cuba is under construction (only $75 \%$ completed), intended to have two VVER-440 V230 reactors with full containments when completed.

The five hypothetical accidents studied are:

1. the DBA LOCA with ECCS on,

2. an $\mathrm{SBO}$,

3. a SLOCA concurrent with SBO,

4. a LLOCA concurrent with SBO, and

5. a LLOCA concurrent with SBO and with the containment breached at time zero.

MELCOR predicted for the DBA LLOCA neither core damage nor radioactive releases, as expected. For the other four sequences, radioactive releases were predicted with the releases dependent on the level of severity of the accident. The most severe accident (Sequence 5) resulted in the earliest and largest releases to the environment. For the least severe of the severe accident sequences studied, Sequence 2 (the SBO), significant source terms are also calculated to be released after $9 \mathrm{~h}$ into the accident.

The source terms released from the severe accidents studied will be dispersed over the island of Cuba and over the Caribbean sea. Under certain weather conditions, the radioactive plume may travel to Southern Florida. Significant doses could result from some of these environmental releases. 


\section{REFERENCES}

1. R. O. Gauntt et al., "MELCOR Computer Code Manuals," Sandia National Laboratories Report for the U.S. NRC, NUREG/CR-6119, Rev. 1 (SAN97-2398), Vols. 1 and 2, July 1997. Also available on the World Wide Web at the address:

http://www.nrc.gov/RES/melcor_man.html

2. U.S. Department of Energy, "Overall Plant Design Descriptions, VVER, Water-cooled, Water-moderated Energy Reactor," Department of Energy Report DOE/NE-0084, Rev. 1, 1987.

3. Nuclear News, American Nuclear Society, "World List of Nuclear Power Plants, Operable, Under Construction, or on Order (30 MWe and Over) as of December 31, 1997," pp. 3954, March 1998.

4. U. S. Department of Energy, "Improving the Safety of Soviet Designed Nuclear Power Plants," Status Report, Office of Nuclear Energy, Science and Technology, December 1997. 


$\begin{array}{ll}\text { ALS } & \text { Accident localization system } \\ \text { DBA } & \text { Design basis accident } \\ \text { DOD } & \text { Department of Defense } \\ \text { DSWA } & \text { Defense Special Weapons Agency } \\ \text { ECCS } & \text { Emergency core cooling system } \\ \text { LLOCA } & \text { Large loss of coolant accident } \\ \text { LOCA } & \text { Loss of coolant accident } \\ \text { LWR } & \text { Light water reactor } \\ \text { NRC } & \text { Nuclear Regulatory Commission } \\ \text { PWR } & \text { Pressurized water reactor } \\ \text { SBO } & \text { Station blackout } \\ \text { SLOCA } & \text { Small loss of coolant accident } \\ \text { U.S. } & \text { United States } \\ \text { VVER, WWER } & \text { Water-cooled water-moderated energy reactor }\end{array}$




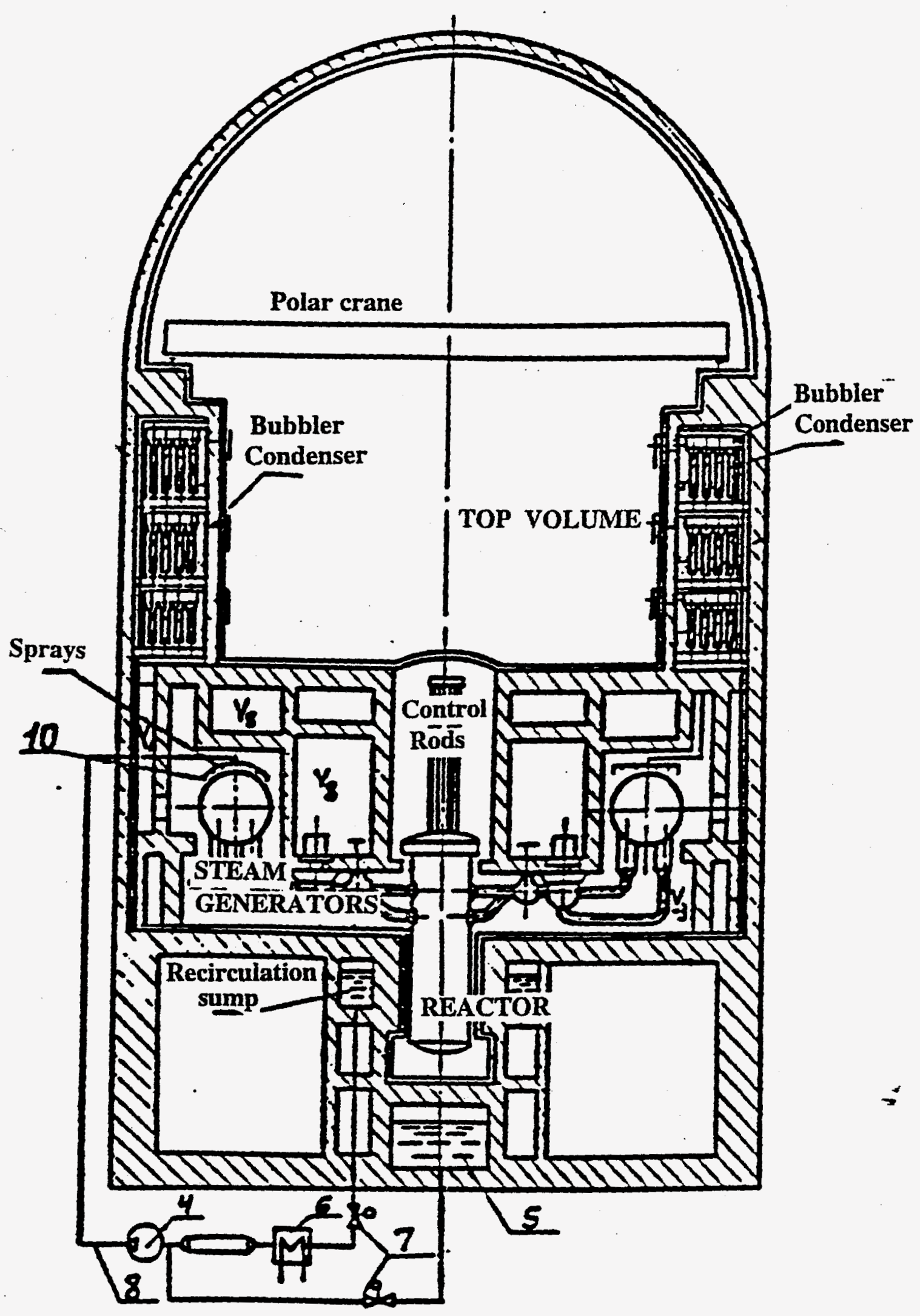

Fig. 1 Containment building of the Juragua Nuclear Power Plant 


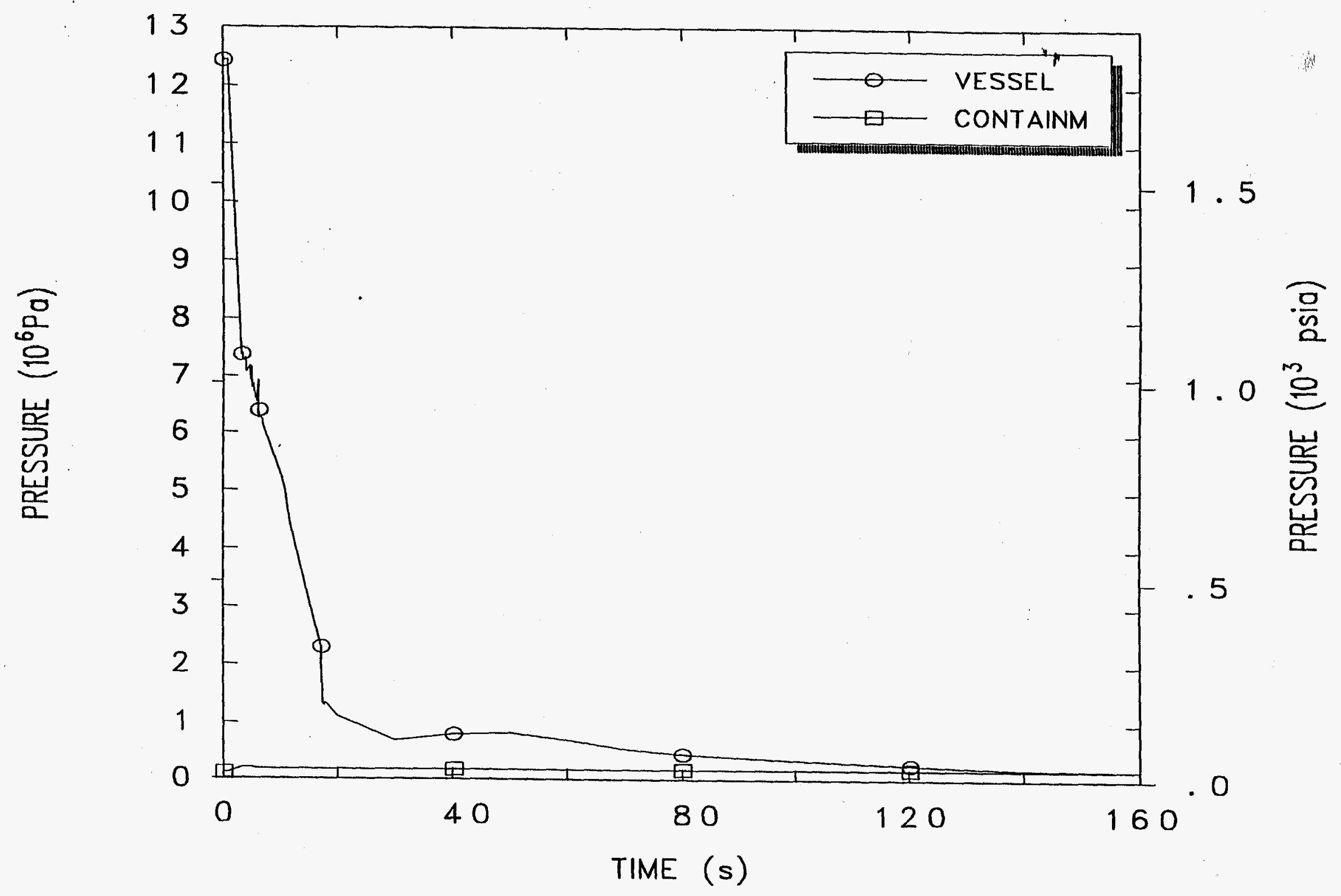

Fig. 2 MELCOR-calculated vessel pressure for the DBA LLOCA 


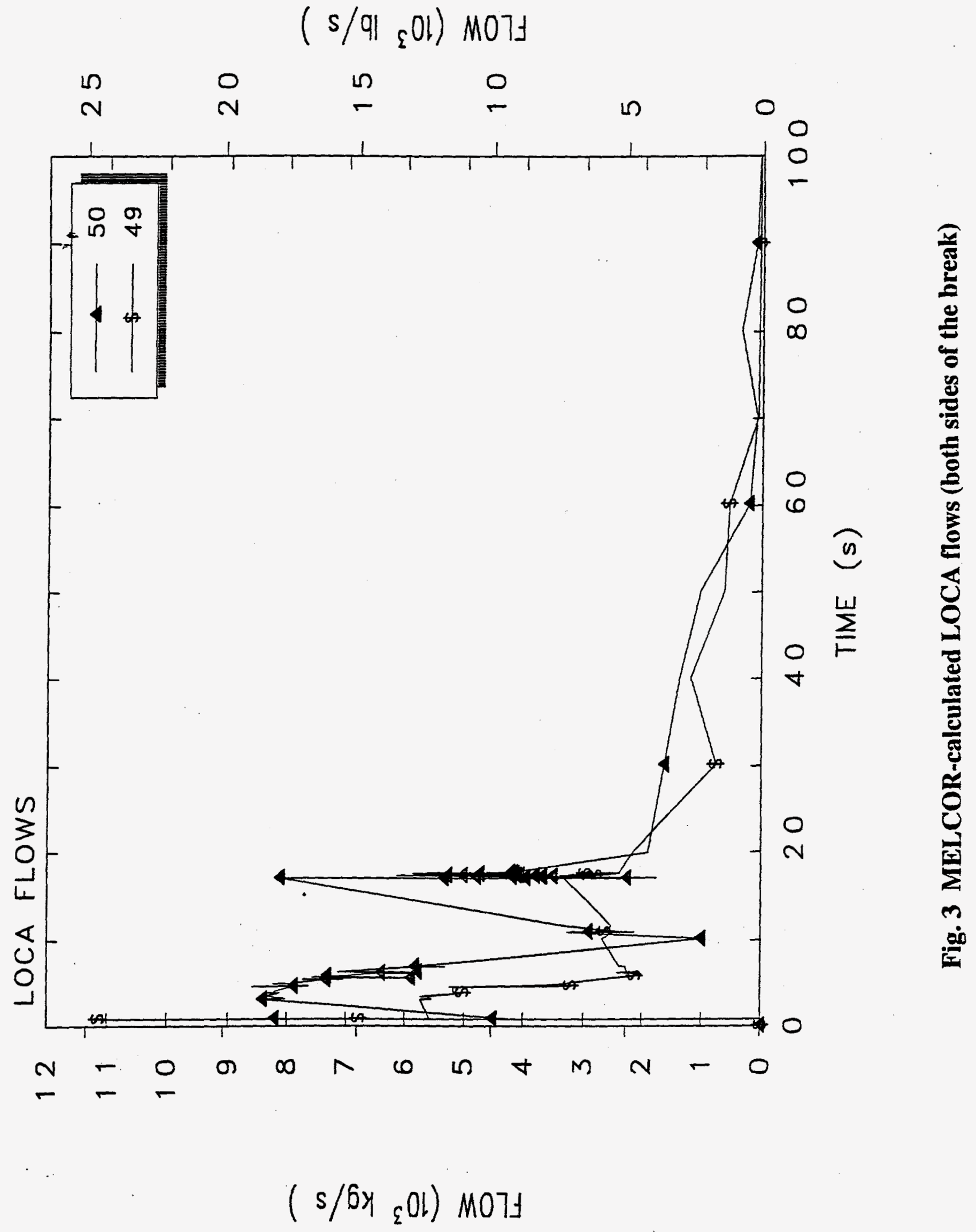


(pisd) Jynssayd

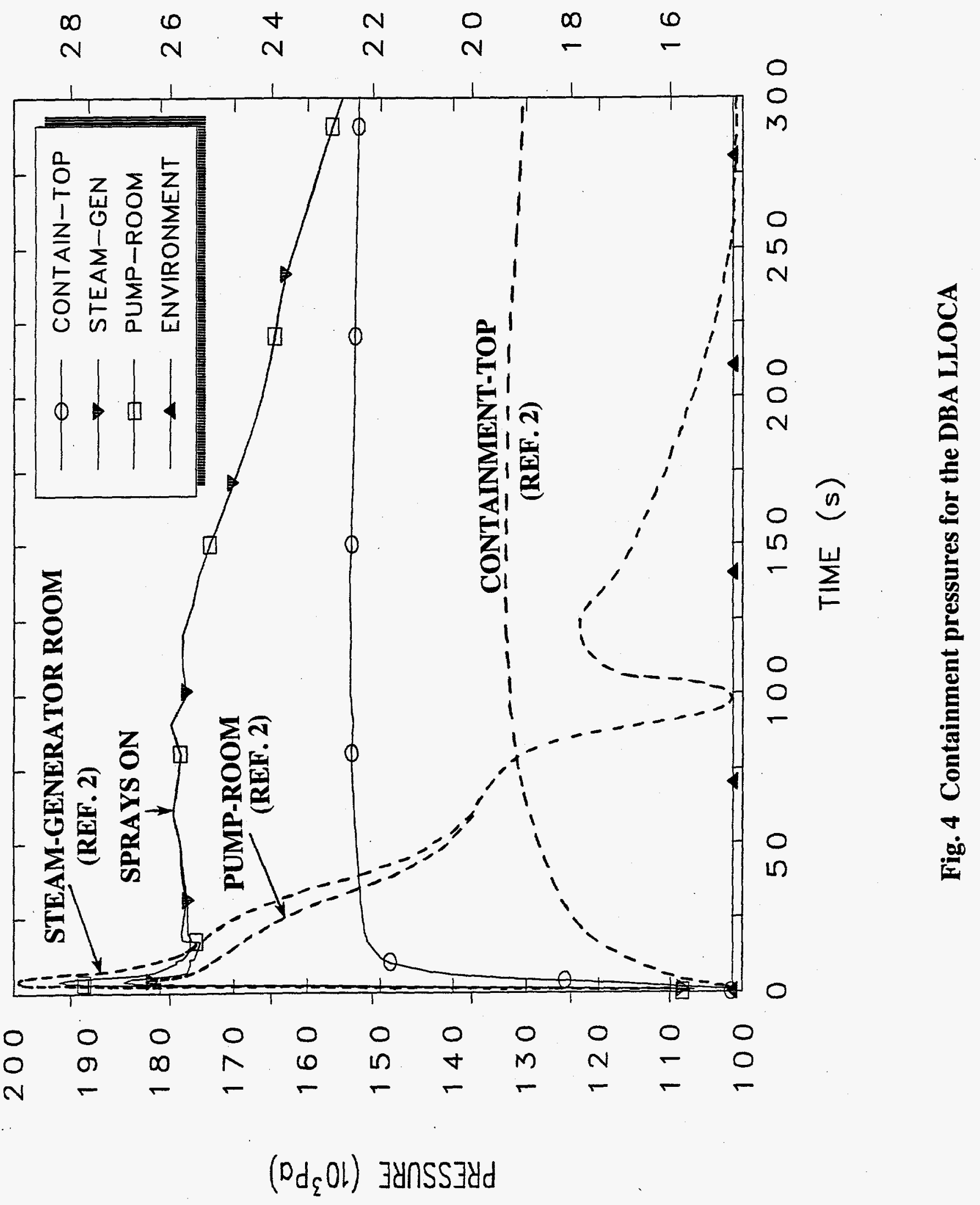




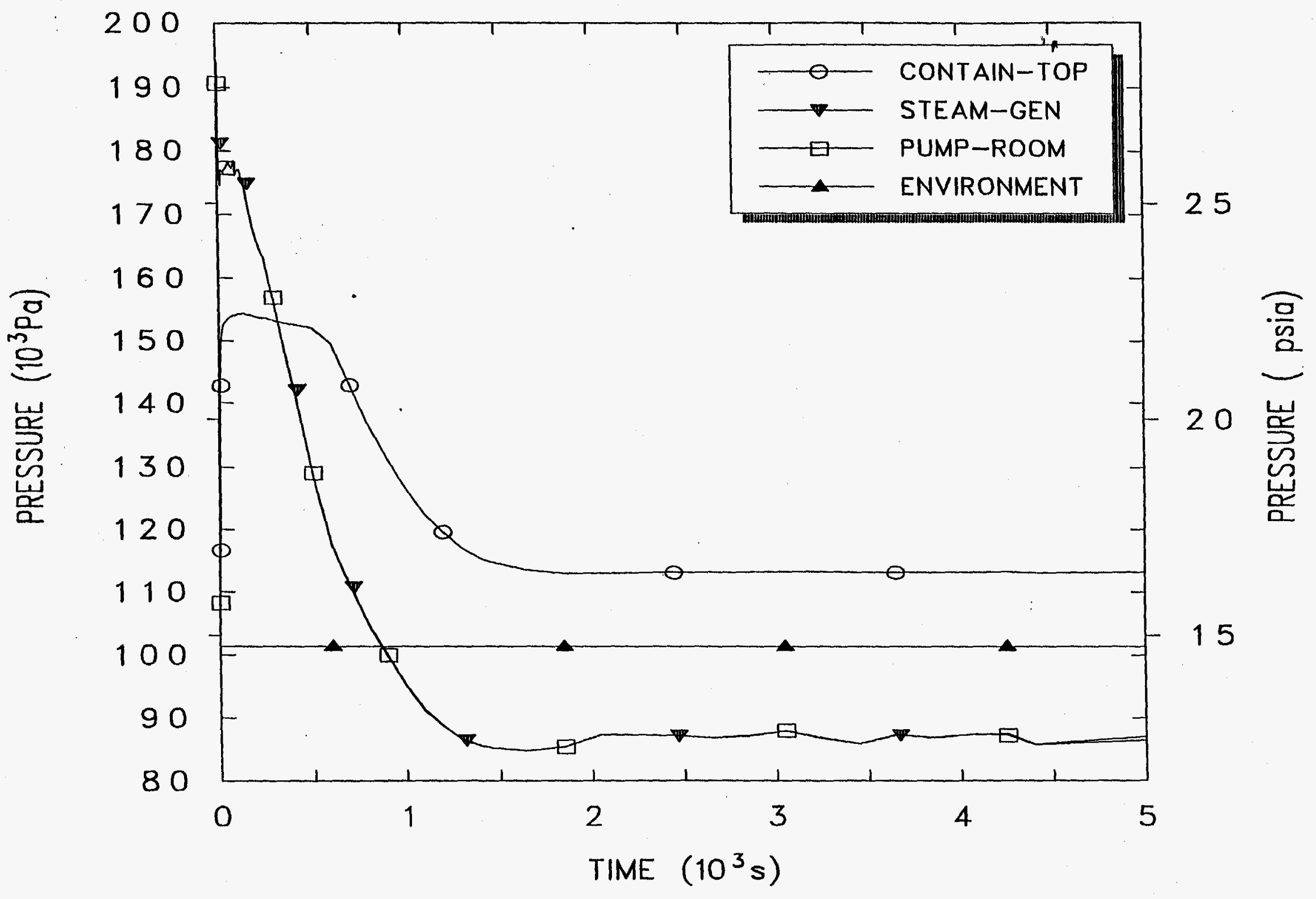

Fig. 5 Containment pressures for the DBA LLOCA (full transient) 


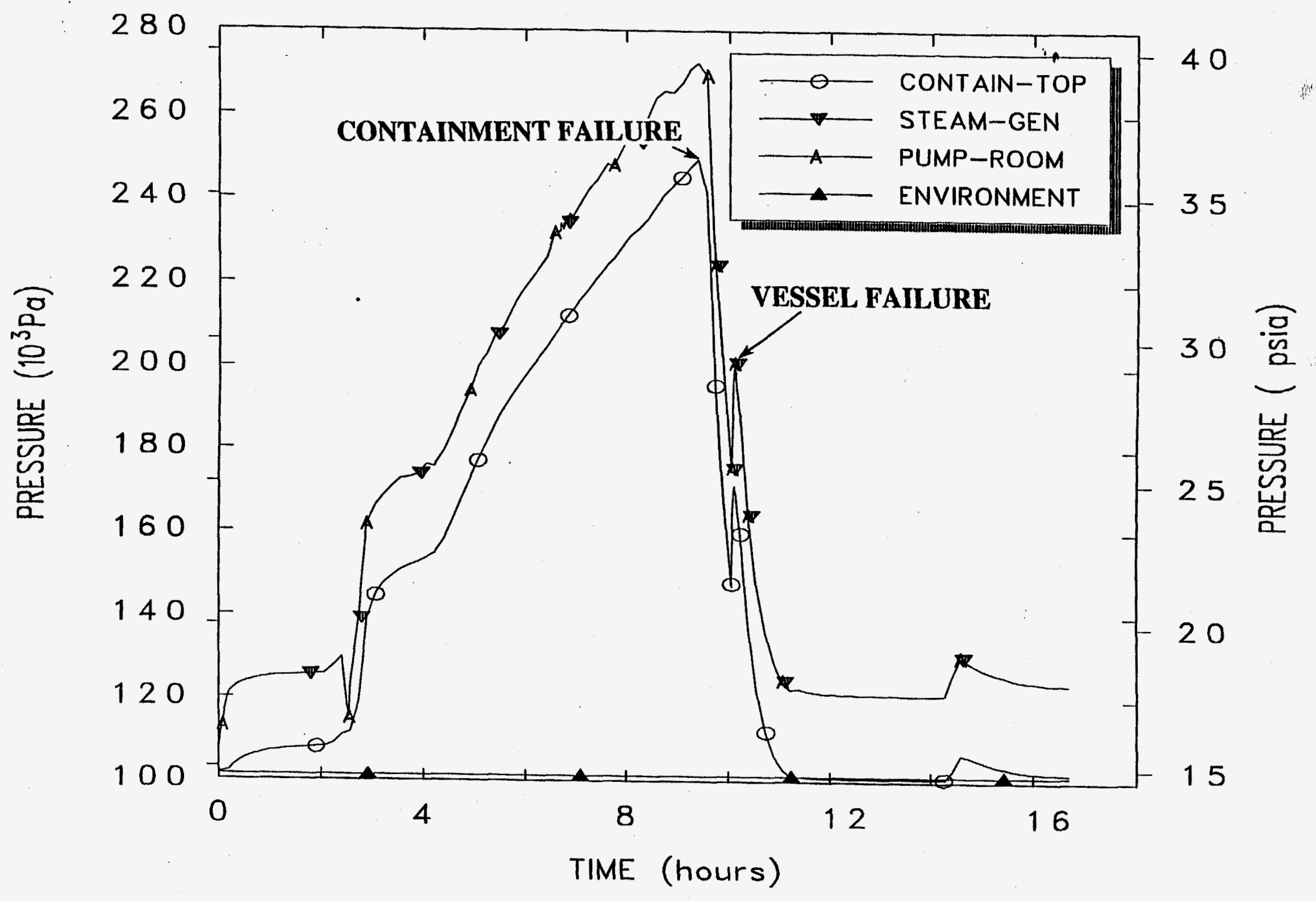

Fig. 6 Containment pressures for the station blackout sequence 


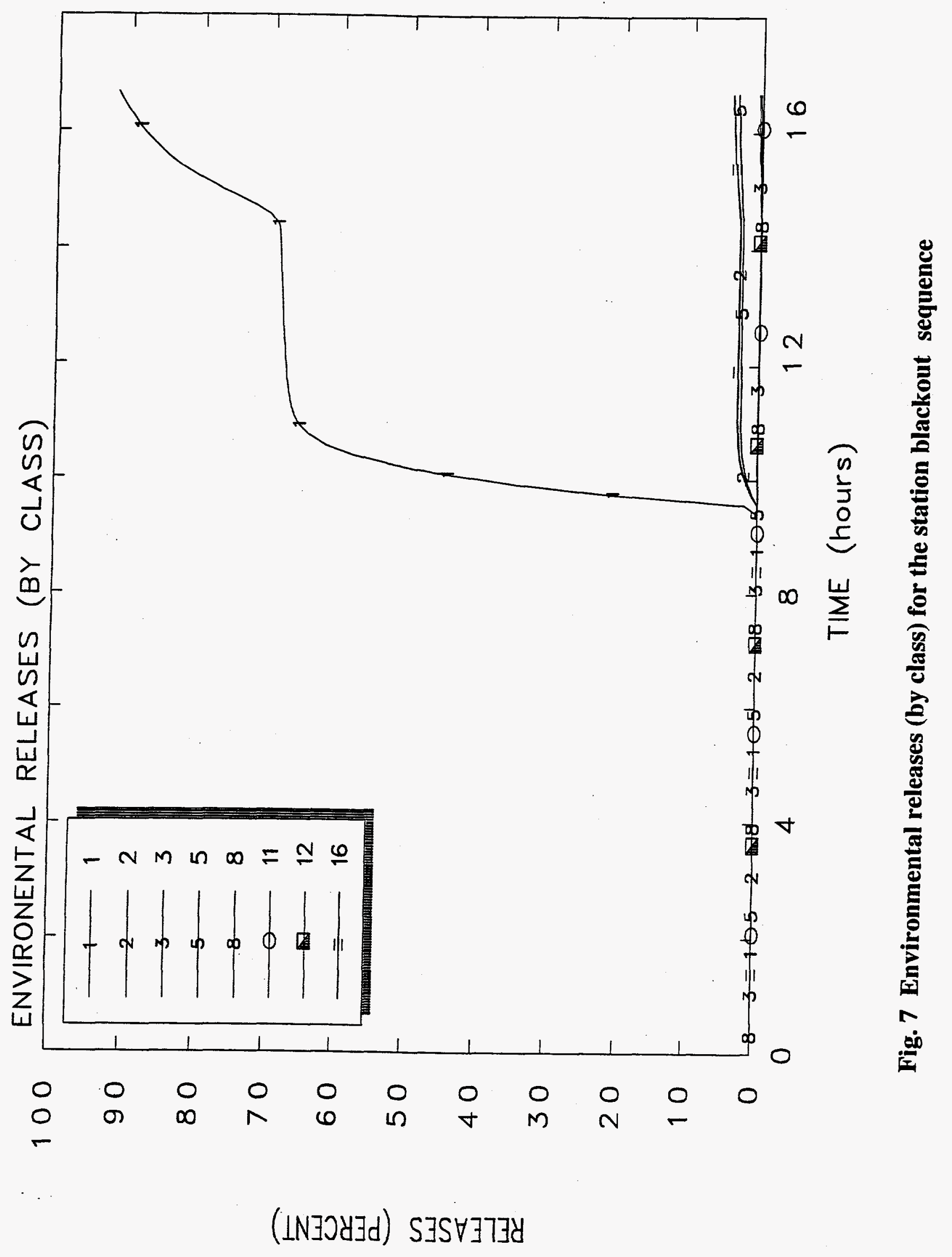




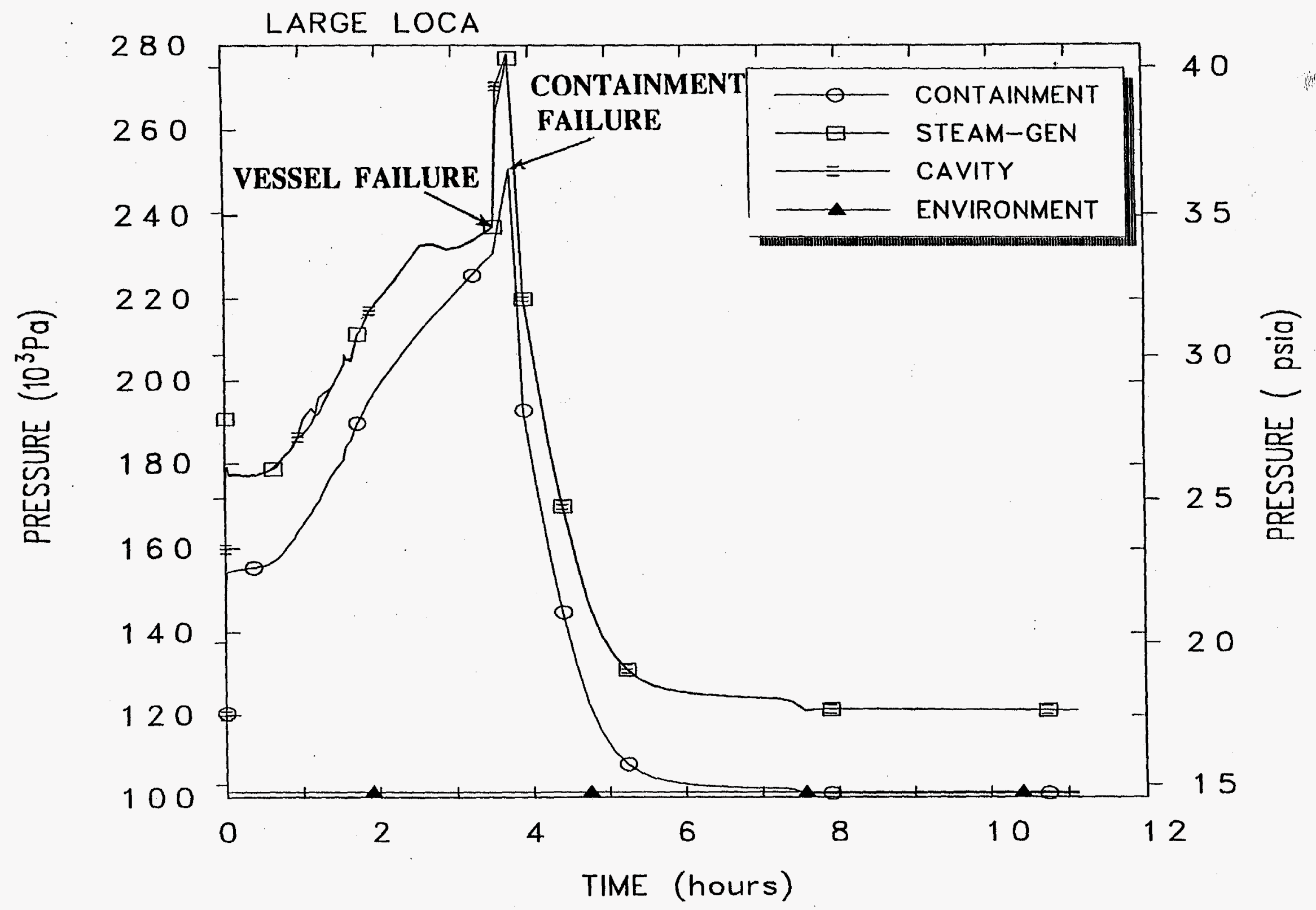

Fig. 8 Containment pressures for the LLOCA + SBO sequence 


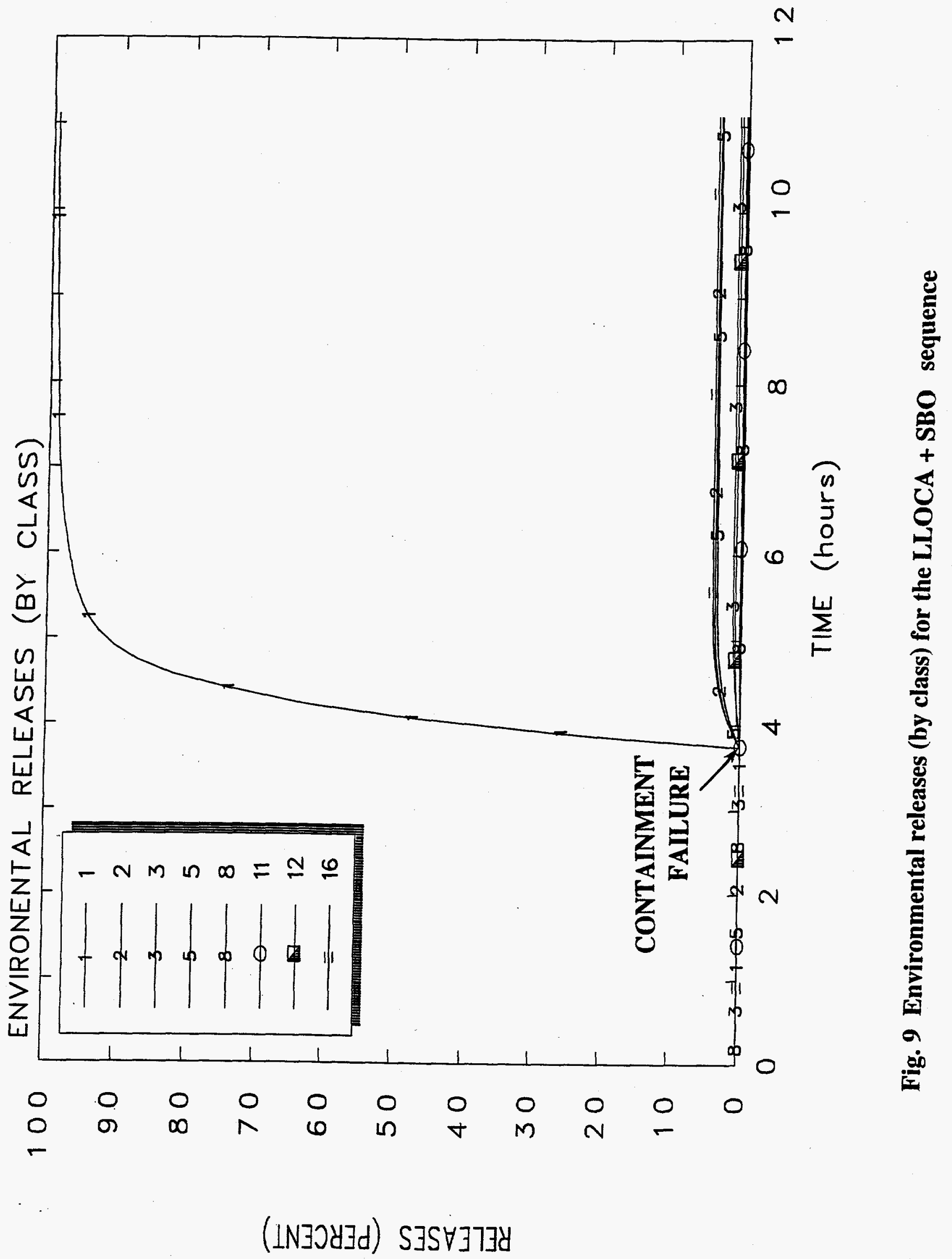




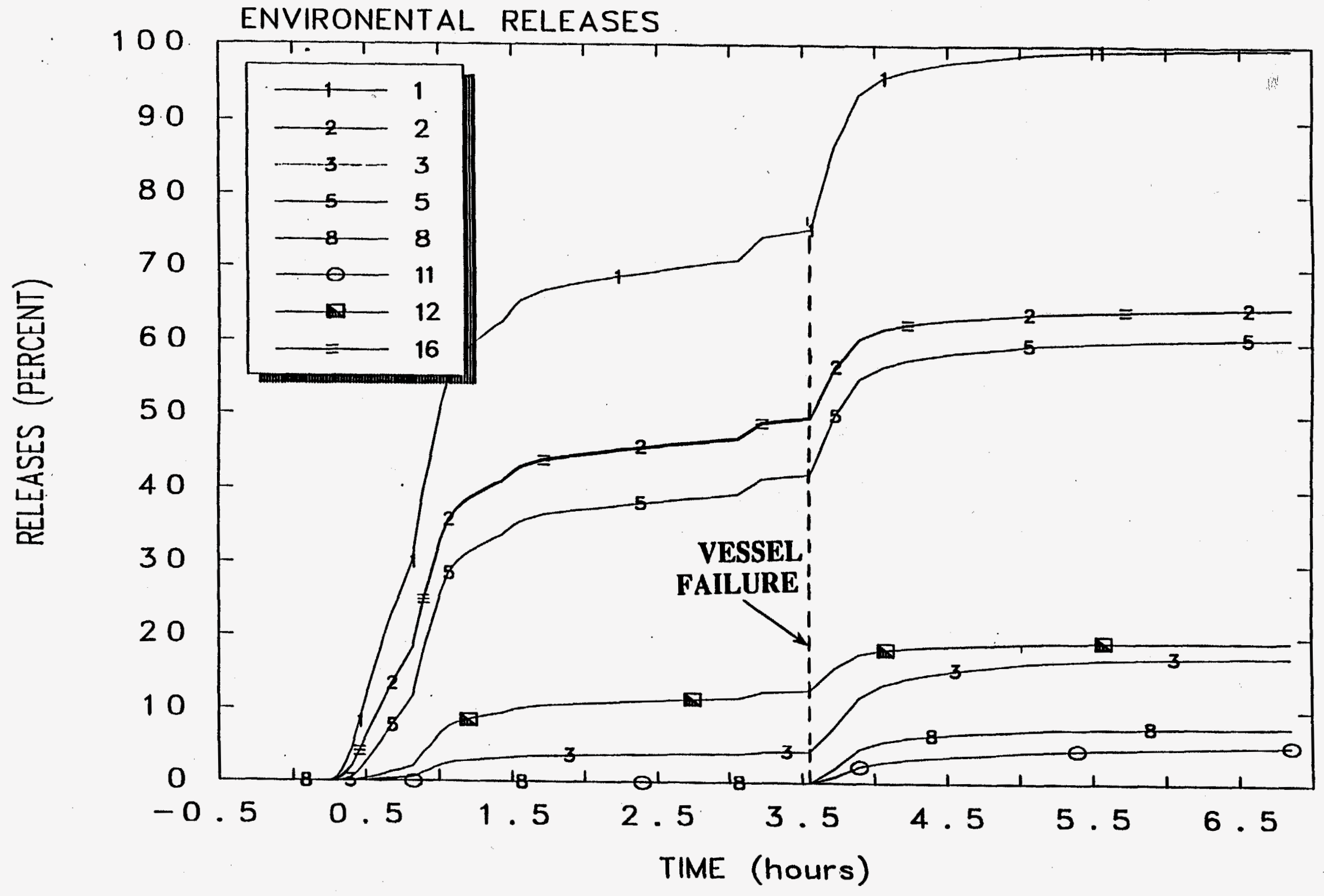

Fig. 10 Environmental releases (by class) for accident sequence 5 